
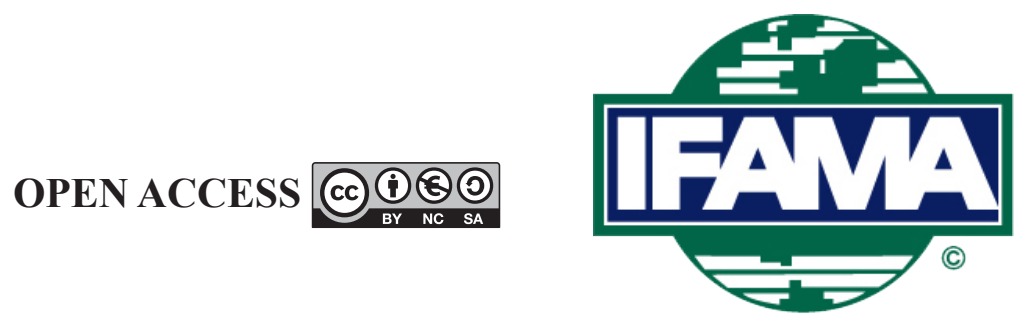

International Food and Agribusiness Management Review

Volume 24, Issue 2, 2021; DOI: 10.22434/IFAMR2019.0154

Received: 23 September 2019 / Accepted: 9 November 2020

\title{
Local industrial policies and development of agricultural clusters: a case study based on a tea cluster in China
}

\section{CASE STUDY}

\author{
Lyuhang Zhao ${ }^{\mathrm{a}}$, Jianqing Ruan ${ }^{\circledR b}$ and Xinjie Shi ${ }^{\mathrm{c}}$ \\ ${ }^{a}$ PhD student, ${ }^{b}$ Professor, ${ }^{c}$ Assistant Professor, China Academy for Rural Development, Qizhen Building, \\ Zijingang Campus, Zhejiang University, 866 Yuhangtang Rd, Hangzhou 310058, China P.R.
}

\begin{abstract}
The purpose of this study is to discuss the effectiveness of local industrial policies and show that effective industrial policies contribute to both the evolution and development of the cluster in the Chinese context, based on comparative advantages and market failures. We adopted a single case study method and conducted interviews with 30 stakeholders in the tea clusters; a documentary investigation was also used as a supplement. This case study finds that local industrial policies have played an important role when market failures occur in the development of agricultural clusters. The local government implemented a series of industrial policies to promote the progress of the tea industry at various stages of development. The case study further demonstrates what can be considered as an effective industrial policy in the dynamic process of agricultural development. This case also provides empirical evidence for local governments to remain sensitive to challenges and to develop timely industrial policies when an industrial cluster is faced with either opportunities or crises. Therefore, it has implications for local governments that need to improve agriculture in undeveloped regions.
\end{abstract}

Keywords: local industrial policy, effective industrial policy, comparative advantage, agricultural cluster JEL code: L78, O25, R58

\footnotetext{
(i)Corresponding author: ruanjq@126.com
} 


\section{Introduction}

In the past 30 years, there have been a large number of agricultural industrial clusters that have had positive effects on achieving rural industrialization, improving farmers' income, and relieving rural poverty in China (Zhang and Ruan, 2011). However, insufficient provision of external public goods with positive externalities hinders the development of agricultural industries, especially at the early stage, in developing countries. Individual firms cannot internalize all these factors cost-effectively. Governments have adopted a variety of measures to overcome market failures and promote industrialization and technological upgrading based on comparative advantages (Lin and Chang, 2009). Local governments helped farmers adapt to the transition from a planned economy to a market economy by formulating industrial policies and adopting corresponding policies to promote the development of industrial clusters during different periods in the case of potatoes (Zhang and $\mathrm{Hu}, 2014$ ).

There is debate about the effectiveness of industrial policies (OECD, 2013). Those who support the implementation of industrial policy believe that industrial clusters are often confronted with externalities in the process of formation, transformation, and upgrading. The government can provide public goods and services that individual enterprises cannot afford to overcome the problems. Therefore, good industrial policies are conducive to promoting the development of clusters (Chang, 2006). However, some scholars doubt the government's ability to design industrial policies that are in accordance with the law of economic development. The government's interference in resource allocation resulted in inefficiencies in economic growth (Baldwin, 1969; Pack and Saggi, 2006). Industrial policies, especially in developing countries, not only lead to price distortions and inefficiencies but also bring problems of rent-seeking and corruption, which raise investment costs and transaction costs (Kang, 2002; Krueger, 1974; Krugman, 1993).

To prove that the industrial policies work, proponents described the government's policies in all stages of development and their influence by taking developed and developing countries as examples (Chang, 2003; Evans, 1995). Although some industrial policies failed (Stiglitz and Yusuf, 2001), Lin (2009) considers that the failure is due to a violation of the country's comparative advantages determined by its endowment structure. Lin (2010) also proposes six strategic steps to identify comparative advantages and implement corresponding industrial policies for developing countries. Some scholars refute his views regarding dynamicchanging markets, information asymmetry, and insufficient capabilities of government (Lin et al., 2011); and the differences in institutional and geographical factors make it hard to find a similar case taken as a reference model, as Lin suggests (Lin et al., 2011).

The previous literature focused mainly on specific policies at the national level, and the above debate does not clearly distinguish national industrial policies from local; besides, there is limited literature concentrating on industrial policies in a developing country context. Regions have comparative advantages and specific industries, and the central government often encounters the problem of information asymmetry when designing industrial policies at the local level. Additionally, most of the policies try to improve the development of the whole industry or non-farm sectors, while agriculture is still one of the primary sources of farmers' income growth in developing countries. It is difficult for the central government to formulate a policy that applies to all industries under different conditions. Therefore, there is an imminent need for case studies to find how local governments design corresponding industrial policies to promote agricultural clusters when market failures occur in the context of developing countries.

It is quite common for local governments to support regional economic development based on industrial clusters in China (Long and Zhang, 2012; Ruan et al., 2014; Zhang and Hu, 2014; Zhang and Ruan, 2011). Drawing on these findings, we attempt to answer the following key questions:

- What industrial policies were designed during the development of the agricultural industrial cluster in China?

- What can be considered an effective industrial policy? 
Using the case of tea clusters in Kaihua County, Zhejiang Province, this study contributes to and engages with the policy design and agricultural cluster literature by illustrating how local governments design industrial policies based on comparative advantages and market failure and what effects of local policies on the agricultural cluster in China. The remainder of this study is organized as follows. We first review the industrial policy and its related concepts. Second, the methodology of the case study is provided, including data collection and analysis; and third, the study reports the findings on how local governments design effective industrial policies. The questions are answered, and the theoretical and policy contributions of this study are elaborated in the discussion. Finally, we present conclusions, limitations, and future research directions.

\section{Literature review}

\subsection{Definition of industrial policy}

The term 'industrial policy' comes from a speech titled 'Industrial Policy in Japan,' which was made by the Japanese Ministry of International Trade and Industry at the Organisation for Economic Co-operation and Development (OECD) Conference in 1970 (Su, 2010). With some developing countries subsequently using as supplements to fiscal and monetary policies to promote economic development (Johnson, 1982), industrial policies received widespread attention. Although mainstream Western economists questioned the necessity of industrial policy since its inception, it played a pivotal role in protecting the infant industry in developed countries (Chang, 2003; Stiglitz, 2015).

The existing literature indicates that the definition of industrial policy is still controversial (Lee et al., 2012). For instance, Evenett (2003) notes that industrial policy means different things to different people. Johnson (1982) believes that industrial policy is a general concept that the government intends to develop and restrict domestic activities to obtain competitiveness. Itoh (1991) defines industrial policy as a policy implemented to improve the economic welfare of the country when inefficiencies occur due to market failure. Different from policies applied to all industrial activities, Pack and Saggi (2006) define industrial policy as government intervention in favor of sectors that are expected to offer better prospects. Hatta (2017) agrees that industrial policy promotes the development of target industries through trade protection, tax incentives, and government credit. Scholars from different countries have different definitions of industrial policy at different stages. Generally, they have two main discussions on the definition of industrial policy: whether an industrial policy has a specific industrial orientation; the other is the relationship between industrial policy and market, that is, whether industrial policy compensates for market failure or distorts the market.

Despite the mixed definition, this extensive literature divides industrial policy into functional industrial policy and selective industrial policy (Altenburg and Lütkenhorst, 2015; Lall, 2001). Functional industrial policy refers to promoting the improvement of the competitiveness of domestic industries by making up for market failures and strengthening market functions, such as vocational training and subsidies for research and development (R\&D). They eschew all forms of selective interventions that favor particular activities or actors over others. The goal of selective industrial policy is to support specific industries to achieve industrial development, and it emphasizes the role of the government in resource allocation (Tassinari et al., in press).

\subsection{Theoretical basis of industrial policy}

Most scholars agree that market failure is the theoretical basis for intervention through industrial policy (Lin, 2019; Stiglitz, 2015). Adam Smith (2011) believes that the market can realize the optimal allocation of resources and oppose government intervention in the economy. At a general level, there is room for government intervention when there are market distortions (such as externalities or market power) or when markets are incomplete (for example, future markets for many goods simply do not exist). Under such market failures, a competitive market system does not yield a socially efficient outcome. 
These studies initiated a new agenda where researchers began to examine the power of industrial policy. Williams (1993) believes that the purpose of industrial policy is to overcome market failures. Rodrik (1996) proposes that industrial policies can effectively compensate for market deficiencies due to inefficient markets in developing countries. Some literature mentions that industrial policies can overcome the externalities brought by R\&D activities (Greenwald and Stiglitz, 2013), such as the spillover of information. The innovation of first movers, whether they succeed or fail, can release adequate information, and their experience offers valuable and free information to other prospective entrants (Hausman and Rodrik, 2003; Krugman and Obstfeld, 2009; Rodrik, 2009).

Relevant literature builds on the view that markets in developing countries cannot provide public goods spontaneously so that government intervention is required (Lin, 2019; Rodrik, 2008). A related issue is the inadequacy of managerial human resources of firms in developing countries, as recent literature increasingly recognizes (Bruhn et al., 2010). The majority of entrepreneurs in developing countries may have inadequate knowledge about management practices, although it plays a critical role in industrial development. Second, there is the potential to produce lemons or low-quality products in the cluster by using inappropriate technologies with the absence of public goods (Otsuak, 2017). Similarly, improvements in hard and soft infrastructure, which cannot be provided by private firms, are required as well to reduce transaction costs with the upgrading of industrial structure (Lin, 2019; Ruan et al., 2014). Besides, scholars also discuss the perspective of imperfect competition and imperfect capital markets, which lead to market failure (Stiglitz, 2015; Warwick, 2013).

\subsection{Effective industrial policy and its effect on agricultural clusters}

Currently, most scholars focus on how to design effective industrial policies (Aghion et al., 2015; Huang, 2018). Previous literature suggests that effective industrial policies should help strengthen market competition (Aghion, 2014; Huang, 2018; Olson, 2000; Stiglitz and Greenwald, 2014). The new structural economics propose that the government needs to design industrial policies based on factor structure endowments and comparative advantages (Lin, 2016). The government does not need to design industrial policies in advance. Wang (2015) considers that the government provides public services and public goods to overcome bottlenecks and reduce transaction costs when problems arise. Some cases of industrial development in the Chinese context also support this view (Zhang and $\mathrm{Hu}, 2014$; Zhang and Ruan, 2011). This proves that effective industrial policies could be designed in the process of industrial development. Additionally, both 'to be' or 'not to be' are key parts of the industrial policy. Despite the intervening market, the effective industrial policy also contains reforms of the government itself and the elimination of erroneous interventions.

While the above literature shows that it is reasonable for the government to formulate effective industrial policies for development, a rapidly growing literature tends to discuss the effect of effective industrial policies on agricultural clusters. Economic development is a dynamic process marked with externalities, and the state must play a proactive role in facilitating an economy to move from one stage to another (Lin, 2019). Sonobe and Otsuka (2006) obtained a model of the impacts of industrial policies on cluster-based development by observing the pattern of development of the developing countries. Some literature discusses and expands the model by producing cases of industrial clusters (Ruan et al., 2014; Zhang and Hu, 2014). The local government needs to formulate industrial policies at different stages to promote the evolution and upgrading of industrial clusters.

Before discussing the case of the tea cluster in Kaihua County, this study describes how local industrial policy helps to overcome successive supply and demand constraints. For a small region, the slope of the demand curve may be flat initially because the scale of production is so small that it can be absorbed by the local market at the early stage. Then, the market becomes saturated, leading to a sudden drop in prices, with industry expanding. However, it is difficult for local governments to directly intervene in demand, as the market always acts as an external factor, therefore early local industrial policies focus more on the change of the supply curve. For example, the local government in Kaihua County has helped cultivate and promote 
improved varieties and set up cooperatives to expand the scale of the industry through industrial policies. This led to a rightward shift of the supply curve and a decline in the equilibrium price. At this stage, farmers will continue to enter the market until the industry's profit becomes zero. When the local industry reaches a certain scale, the development of the clusters by the impact of market demand is more significant. Faced with a complex external environment, the government's industrial policies can help industrial clusters to broaden the market and overcome demand problems, such as building a professional market to attract more traders and creating and fostering their brands. This shows that industrial policies can promote both supply and demand of agricultural industry clusters by providing public brands and public goods such as infrastructure.

\section{Methods}

\subsection{Case selection}

The selected case is a tea cluster in Kaihua County, located in the west of Zhejiang Province (Figure 1). Green tea is one of the main consumer goods and agricultural export products in China; the tea clusters in this province occupy an essential share in the external market, and the case selected in this study is representative.

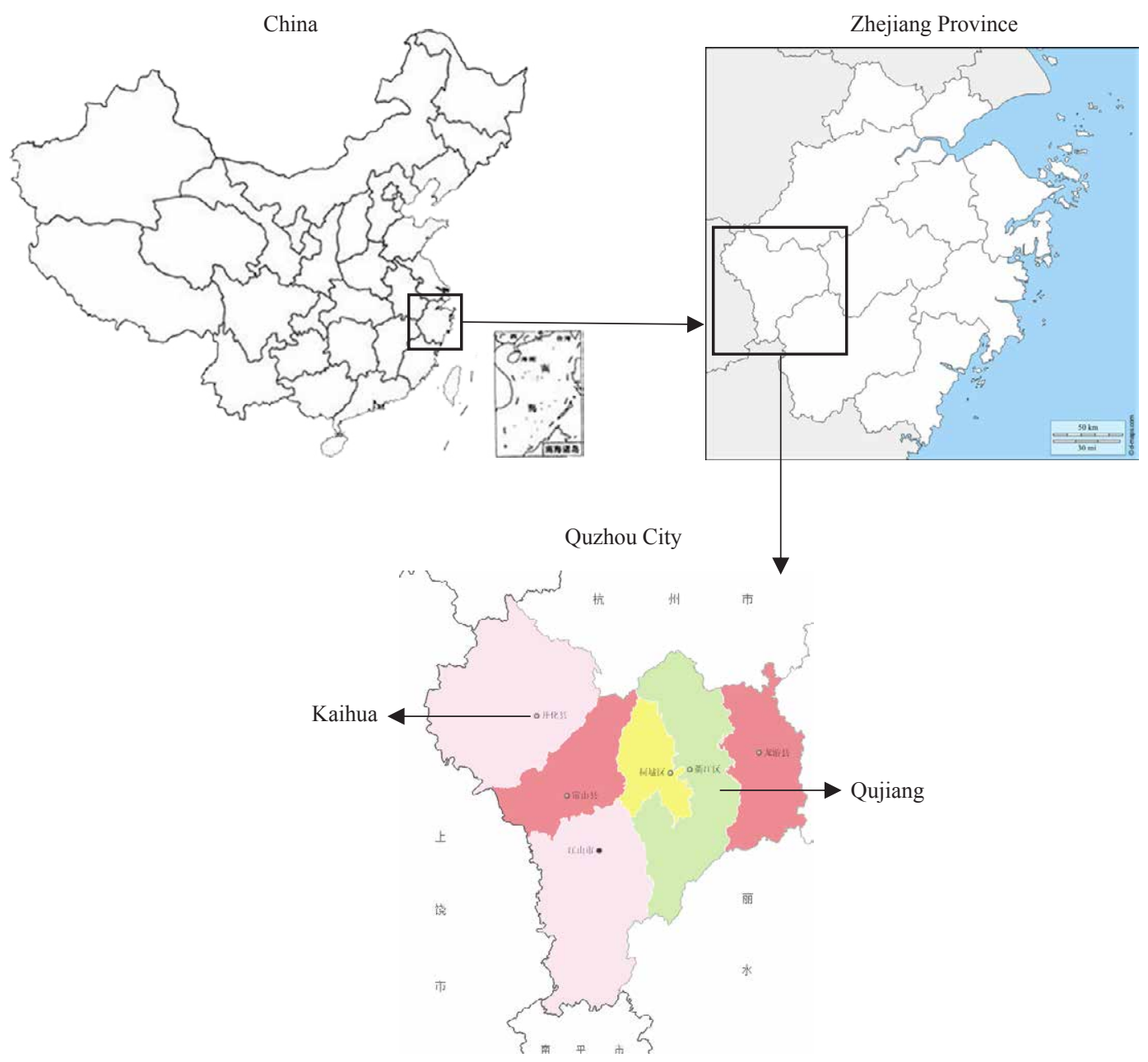

Figure 1. Location of the study area. 
Kaihua was one of the poorest counties with mountainous areas (more than $85 \%$ of region county territory are mountains) and a few fields, which lead to limited agricultural development. Therefore, the tea industry became a key component of agriculture in the county and is one of the most important ways for local farmers to increase their income and escape poverty. Kaihua was one of the most important tea producing and exporting regions in Zhejiang Province since the Ming Dynasty. Compared to other tea-growing regions (e.g. Hangzhou, Shaoxing, etc.) in Zhejiang, Kaihua has more advantageous and suitable environmental conditions for tea cultivation, such as abundant rainfall (1,814 mm per year), fog, diffuse light, and a hightemperature gap between day and night. Moreover, Kaihua is located near the source of the Qiantang River, far from manufacturing districts, which provides a better quality environment for tea growth. In 2014, the sales of tea accounted for approximately $1 / 4$ of the county's agricultural added value and 1/3 of farmers' income (Yu, 2015).

The single case study was chosen for three reasons. First, a case study is a history of a past or current phenomenon, drawn from multiple sources of evidence (Voss et al., 2002). Second, the case method allows the questions of why and how to be answered (Chen et al., 2020; Galli et al., 2017; Yin, 2009). To verify the literature above, this study adopts a single case study method, focusing on how local governments design effective industrial policies according to comparative advantages and market failures. Third, there are limited case studies devoted to industrial policies for agricultural clusters in the Chinese context, as previous literature tends to focus on non-farm policies or cases in Western countries. The case of the Kaihua tea cluster could be used as a reference and provide an exemplar for developing countries for application.

Problems associated with using a single case include the risk of misjudging an event and exaggerating easily available data (Jia, 2016). It is difficult to tell whether industrial policies are influencing the success of the tea case in Kaihua or whether it may be just an accidental phenomenon. This study, therefore, uses the development of the tea industry in Qujiang District, whose initial conditions are quite similar to Kaihua for comparison to support our point of view. It stands to reason that, as illustrated later in the study, local governments need to design industrial policies to support industrial clusters, because the binding constraints of industrial development are often location specific and change constantly.

\subsection{Data collection}

Yin (2009) explains that case study research should be followed with six sources of evidence including documentation, archival records, interviews, direct observation, participant observation, and physical artifacts. The research derives evidence from a collection of interviews and documentary investigation.

The interviews were conducted with 30 major participants, including the director and three officers of the special bureau, five managers of tea factories or cooperatives, ten tea farmers, a manager of the tea market, and ten traders. All the interviews were recorded with the respondents' permission, and some of them were interviewed informally two times or more. Considering the importance of rigor and accuracy of the data, the first author kept in touch with some key interviewees via telephone and WeChat after field trips to check information. Moreover, this study utilizes data from documents to support the information. The data used in this study were from the following sources: (1) macro data including output value, cropping area, and brand value from official statistical yearbooks and previous literature; (2) data in the early stage from documentation and archival records edited by officials and agricultural technicians in the 1980s and the 1990s; and (3) development history and major events provided by policymakers, officials, tea farmers, and agents.

\subsection{Data analysis}

To answer these questions, we attempt to discuss the development process of the Kaihua tea cluster and the industrial policies of local government designs. First, all the authors read the interview scripts and related documents and transferred all the data into a unified manner for comparison. Second, the information and data were classified and summarized to identify related subthemes. Third, the manuscripts related to the 
identified subthemes were analyzed to identify themes. Finally, the first author made dynamic contact with key interviewees for reliability and quality control.

\section{Development of the tea cluster in Kaihua county}

Tea is a main agricultural product in Kaihua County. It was produced initially as a raw commodity. After the reform and opening up, the local government began guiding the tea industry to adjust its structure and encourage farmers to produce famous tea when the single product could not meet the demand for high-quality products in the tea market. In 1978, after the 'Moganshan' tea production meeting, supply and marketing cooperatives and forestry departments began to cooperate to replant and conduct a trial of a local tea named 'Kaihua Longding' in the following year. In 1981, the total tea cropping area in Kaihua County was 8,460 ha, and the total output and total output value of tea reached 2,700 tons and 4.65 million USD ${ }^{1}$, respectively. Foreign exchange accruing from tea accounted for $65 \%$ of the total amount of foreign exchange in the county. (Editorial Committee of Forestry Chronicles of Kaihua County, 2011). Given the development of the tea industry, the local government strengthened its support for the tea cluster, leading to the continuous expansion of the cluster, in which the production of famous tea gradually became more important. Figure 2 shows that the proportion of the output value of famous tea in the total output value of tea continues to rise, although the output of famous tea accounts for only a small part of the tea industry. In 1997, the value of 'Kaihua Longding,' the famous tea, accounted for $58.5 \%$ of the total tea output value (Ju, 1998).

After 2004, the local government paid attention to the development of famous tea. The output value of famous tea and its importance in agriculture increased (Table 1). The tea industry became one of the most important agricultural industries in Kaihua. In 2008, there were 100 professional tea villages, 35 professional tea cooperatives, and more than $1 / 3$ of the agricultural population participated in the tea industry in Kaihua County (Cheng and Yu, 2009). By 2014, the tea cluster consisted of 225 professional tea cooperatives, 77 enterprises, a labor force of 100,000, including 25,600 households (39,000 farmers) engaged in cultivation, 1,200 sales staff, and more than 100 technical staff (Yu, 2015).

\footnotetext{
${ }^{1}$ All figures concerning prices, values of output and other financial outcomes are converted to USD based on the exchange rate every December on a 40 -year basis.
}

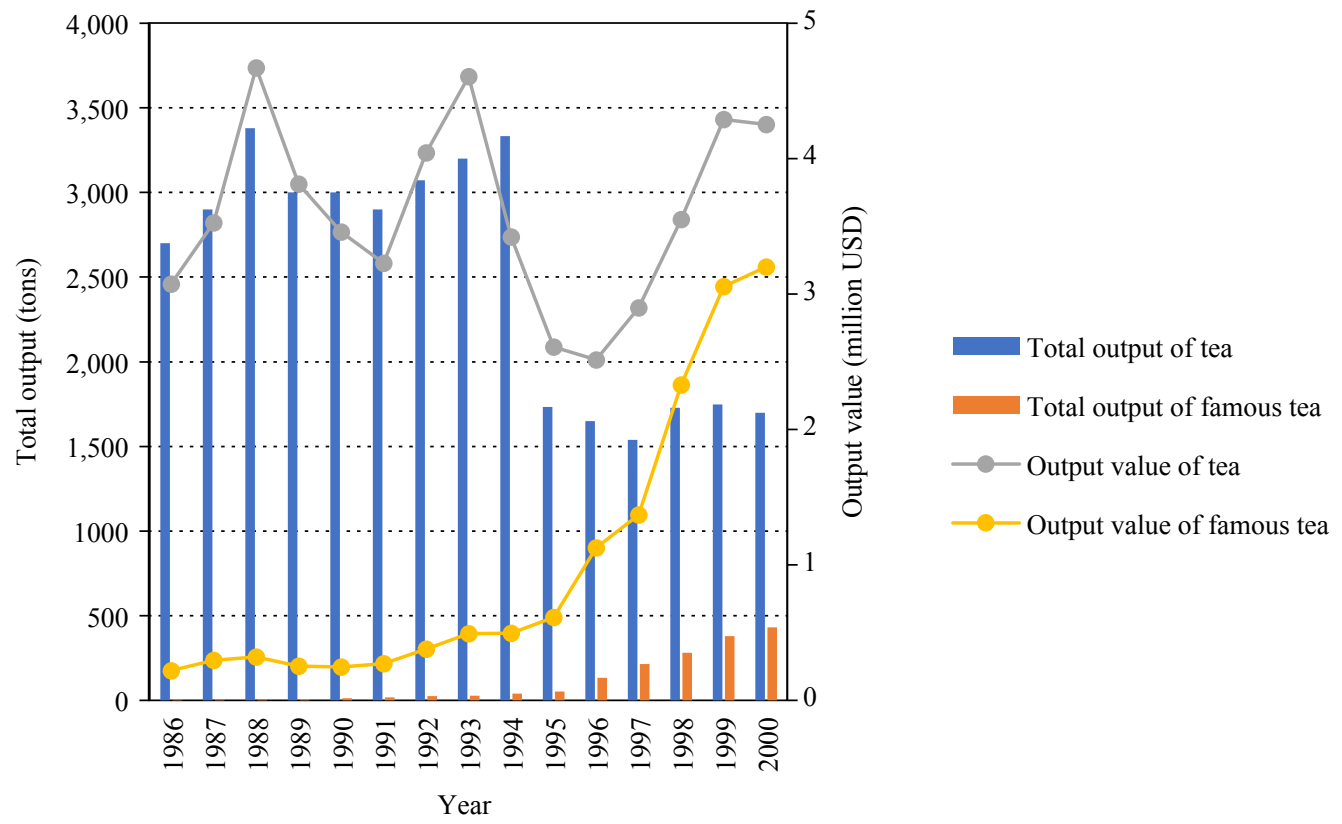

Figure 2. Development of tea industry in Kaihua County (1986-2000) (Editorial Committee of Local Chronicles of Kaihua County, 2010). 
Table 1. Development of the tea industry in Kaihua County (2004-2017). ${ }^{1,2}$

\begin{tabular}{llllll}
\hline Year & $\begin{array}{l}\text { Output value } \\
\text { of agriculture } \\
\text { (million USD) }\end{array}$ & $\begin{array}{l}\text { Total tea cropping } \\
\text { area } \\
\text { (ha) }\end{array}$ & $\begin{array}{l}\text { Total output of } \\
\text { famous tea } \\
\text { (tons) }\end{array}$ & $\begin{array}{l}\text { Output value of } \\
\text { famous tea } \\
\text { (million USD) }\end{array}$ & $\begin{array}{l}\text { Output value } \\
\text { of famous tea } \\
\text { (USD/ton) }\end{array}$ \\
\hline 2004 & 105.00 & 5,520 & 1,025 & 21.02 & 20,510 \\
2005 & 119.70 & 5,416 & 878 & 19.47 & 22,180 \\
2006 & 130.75 & 5,279 & 1,068 & 24.37 & 22,820 \\
2007 & 141.32 & 5,942 & 1,288 & 30.36 & 23,570 \\
2008 & 168.49 & 5,915 & 1,324 & 32.15 & 24,280 \\
2009 & 176.87 & 5,857 & 1,605 & 42.47 & 26,460 \\
2010 & 190.93 & 5,848 & 1,434 & 43.56 & 30,370 \\
2011 & 216.09 & 5,806 & 1,650 & 54.59 & 33,080 \\
2012 & 219.19 & 5,813 & 1,815 & 65.74 & 36,220 \\
2013 & 228.51 & 5,322 & 1,523 & 63.58 & 41,750 \\
2014 & 221.47 & 6,820 & 1,686 & 69.00 & 40,920 \\
2015 & 212.19 & 6,876 & 1,851 & 75.84 & 40,970 \\
2016 & 200.33 & 6,790 & 1,758 & 68.94 & 39,220 \\
2017 & 208.59 & 6,861 & 2,126 & 80.15 & 37,700 \\
\hline
\end{tabular}

${ }^{1}$ Output value of agriculture and famous tea are based on the price level in 2004; the output value of agriculture output fluctuation of famous tea was caused by climate disasters such freeze injuries and droughts; the decline in output value was caused by the rise in the price index and the US dollar exchange rate after 2014.

2 The numbers of output value of agriculture and cropping area are from Quzhou Statistical yearbook (Quzhou Bureau of Statistics, 2018); the numbers of output and output value of famous tea come from Statistical Bulletin of National Economy and Social Development in Kaihua County (Kaihua Government, 2018) and Kaihua yearbook (Editorial Committee of Local Chronicles of Kaihua County, 2015)

Producing and processing tea is one of the main ways for local farmers to increase their income. From 2007 to 2009, the local government invested 2.87 million USD in technical upgrading, construction of tea plantations, market expansion, and deep processing, which increased the number of jobs by 4,566 and farmers' income by 8.06 million USD (161 USD per person). By 2011, farmers acquired 11.92 million USD (197 USD per person) more from the tea industry (Yang and Cao, 2011). Meanwhile, the tea industry also became one of the most important ways to protect the region against poverty. For example, Chaling Village was one of the poorest villages in Kaihua County. To increase their income, the villagers transformed their occupations to engage in producing tea. In total, $90 \%$ of villagers (more than 160 households with 500 people in the village) acquired income (approximately 3,223 USD per household) rely on tea production (Hu and Zheng, 2015).

\section{Local industrial policies in the development of the tea cluster}

The advantageous natural conditions in Kaihua County made it easy to develop the tea industry, which has been one of the main sources of farmers' income in the past four decades. Local industrial policies play an important role in the process of industrial development and the evolution of clusters. Therefore, the policies from Kaihua County give local governments some inspiration to develop agriculture industry clusters depending on comparative advantages and market failures. This section discusses industrial policies and their effects on industry clusters.

\subsection{Overcoming production bottlenecks}

Tea production is a basic part of the development of tea clusters. However, production bottlenecks, including breeding improved varieties and promoting mechanization, were the first challenges exposed in the early stage, although nature bestowed Kaihua County with advantageous conditions. 
With an increasing supply of tea, consumers demand more diverse and standardized production. However, it lacked multiple varieties of tea, and nearly all the tea was provided manually, making it difficult to adapt to the market. Only a few tea plantations delivered some improved varieties from Fujian Province, while most of them selected some local varieties, and there were a limited number of machines employed in producing homogeneous products in the 1980s. Unsalable products and price drop demotivated farmers in 1982. Farmers began to switch from tea planting to growing other products, such as fruits and bamboo, resulting in the tea industry shrinking. Until 1985, only 1,926.5 mu (approximately $128.43 \mathrm{ha})^{2}$ of tea plantations imported and grew white tea from Fujian Province (Rui, 1999), accounting for only 1.6\% of the total area of tea plantation.

In consideration of market demand, the local government took a step to develop better varieties. To promote improved varieties, the technical staff introduced some seeds from Fuding and tested them in Youchuan village as a pilot. Then, the county government began to import seeds and seedlings and cooperate with local tea plantations in developing the famous tea. This variety turned out to be superior to other varieties at the time. In 1988, the average output value of improved varieties reached 676 USD per mu, whereas the average output value of common varieties was only 118 USD per mu in the same base. Conversely, the price of improved varieties was 5.36 USD per kilogram higher because of its high quality (Rui, 1999). Table 2 shows that the local government imported improved varieties from other counties in the initial stage. In 1993, the local plantations produced more seeds and seedlings than they imported, and they started to export the improved varieties to surrounding counties, such as Xin'gan County, Liuhe County, and Chun'an County (Rui, 1999).

Moreover, the county government offered a series of subsidies to support the development of improved varieties and mechanization. For instance, the local government invested 84,496 USD to support the construction of tea bases from 1985 to 1989. After 1991, the financial department began to subsidize farmers who developed famous tea; the tea bases that expanded the scale of famous tea (more than $10 \mathrm{mu}$ ) would get $18.35 \mathrm{USD} / \mathrm{mu}$ as financial subsidy. They could also obtain tax preferences (25-50\%). Then again, bases were able to obtain corresponding subsidies (12-242 USD) for either purchasing different machines or hiring skilled workers. Up to 1998, the total area of tea plantations cultivating clonal cultivars reached 10,158 mu (approximately $677.2 \mathrm{ha}$ ), which accounted for $10 \%$ of the total tea plantations, and was 5.27 times as large as the area in 1985 (Rui, 1999). Farmers and firms purchased 267 professional machines when approximately 52.96\% of famous tea with high prices was produced by machinery (Zhu, 1999).

$21 \mathrm{ha}=15 \mathrm{mu}$.

Table 2. Cultivation of improved varieties in Kaihua County (1986-1996) (Committee on Literature and History of CPPCC of Kaihua, 1999). ${ }^{1}$

\begin{tabular}{llccc}
\hline Year & $\begin{array}{l}\text { Seeds from import } \\
\text { (tons) }\end{array}$ & Seedlings from import & Seedlings & $\begin{array}{c}\text { Area of new } \\
\text { plantations }\left(\mathbf{m u} \mathbf{2}^{2}\right)\end{array}$ \\
\hline 1986 & 10.05 & - & - & 501 \\
1987 & 18.31 & - & - & 818 \\
1988 & 7.75 & 32,000 & 706,000 & 403 \\
1989 & - & $1,086,000$ & 602,000 & 337 \\
1990 & - & $1,100,000$ & 475,000 & 436 \\
1991 & - & 918,000 & 750,000 & 386 \\
1992 & - & $5,016,000$ & $5,369,000$ & 303.8 \\
1993 & - & $4,119,000$ & $3,860,000$ & $3,381.6$ \\
1994 & - & - & $2,694,000$ & 2,428 \\
1995 & - & - & $2,691,000$ & 1,418 \\
1996 & - & - & 866
\end{tabular}

${ }^{1}$ The average survival rate of tea seedlings was only $39.5 \%$ because of drought and frost damage in winter in 1991.

21 ha $=15 \mathrm{mu}$. 
In 2000, the financial subsidy for tea bases increased to $24.16 \mathrm{USD} / \mathrm{mu}$. The scale of the tea cluster expanded rapidly, with 12,000 mu (approximately $800 \mathrm{ha}$ ) of tea plantations established in the next four years. Meanwhile, the tea cluster included 392 processing factories with more than 1,830 machines. In 2014, there were 6,820 ha of tea plantations, approximately $60 \%$ were clonal cultivars, and more than $95 \%$ of famous tea was produced by machinery. Both improved varieties and mechanization had positive effects on the tea cluster in Kaihua County.

The local government helps to overcome production bottlenecks and reduce farmers' risk by providing industrial policies for R\&D at the primary stage. Agriculture is an activity burdened by multiple risk factors. Most of the farmers, the main participants of agricultural clusters, tend to avoid risks (Wang and Huang, 2016). Small farmers lacked the motivation and ability to cultivate new varieties and make use of professional machines because of limited capital and high costs. The industrial policies played the following three roles. First, the local government helped some local tea plantations to introduce improved varieties and machines for testing, and at the same time compensated other farmers for the externality of these plantations. Having observed the success of first movers, farmers started to produce standardized famous tea spontaneously through imitation. Second, the free pieces of training held by the local government and subsidies also helped farmers to undertake the large-scale expansion of reproducing the seedlings. Third, using machines can not only improve the overall product quality of the cluster but also significantly reduce costs, especially wages, which reached 22-43 USD per day (Wang, 2017).

\subsection{Establishing industrial organizations}

Agricultural industrial organization is a contractual relationship between farmers and related enterprises, cooperative organizations, or transactions with each other to realize specialized production (Luo et al., 2002). The participants of industrial organizations are not only farmers and enterprises but are also the multilevel government, who provide industrial policies to the tea cluster. Compared to the national-level policies of the central government, local governments could issue local industrial policies that may be more effective in supporting local industrial organizations.

The Chinese central government began to establish a socialist market economy in the 1990s, which led to the rapid expansion of the tea industry and the competitive market. Farmers sold the tea product from Kaihua County as part of other tea brands rather than building their brands in external markets. After the Chinese central government abolished the state monopoly on tea purchasing and marketing, the individual farmers who once relied on a collective economy and a supply and marketing system had to compete by themselves.

Against this background, local farmers who knew little about business skills and price information had little bargaining power. The price was determined largely by outside traders. Moreover, disorderly competition in the Kaihua tea cluster further damaged farmers' benefits. In 1994, 41\% of the products were unsalable, causing great losses to farmers in Kaihua County, and many tea plantations stopped cultivation during the next three years (Editorial Committee of Forestry Chronicles of Kaihua County, 2011). Figure 3 shows that, before 1997, farmers were involved in production and wholesale only as separate individuals, and the local government was more likely to implement policies at the level of production.

Considering the importance of organizations in a competitive market, the county government began to formulate industrial policies (e.g. fostering enterprises and cooperatives, and establishing a tea association) to improve industrial organizations. Collaborating with multiple stakeholders is an essential strategy for the development of private enterprises in China's rural areas (Chen et al., 2020), and it is also applicable in the construction of industrial organizations as well in Kaihua. In 1993, the local government established a special bureau responsible for planning, technology promotion, and brand management of the tea industry. An official leading group in charge of the development of the whole industry was set up with the position of the tea industry going up in agriculture in 1998. This group implemented the 'Procedures of Kaihua Longding,' which provided standards about nursery stock, techniques of cultivation, and process technology 


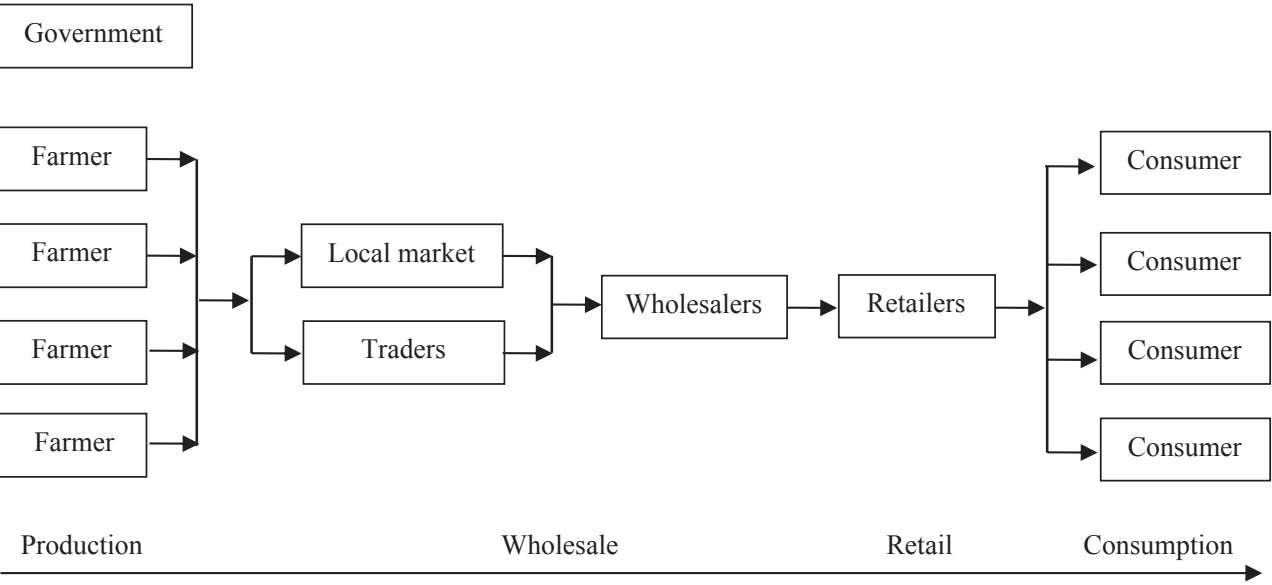

Figure 3. Tea supply chain and organizations prior to 1997.

for fresh leaves and commercial tea. The tea cluster began to establish its industrial system, including private producers, enterprises, and organizations.

First, the county government provided support for private producers. In the early stage, the local government designed industrial policies to encourage and finance farmers with idle land to engage in tea production. The increased participation of different market players improved the system of the tea cluster. These private producers played an important role in the tea industry in the 1990s. However, disordered competition and low quality occurred with many new participants entering the industry, adversely affecting the reputation of the local product.

Then, faced with quality crisis, the leading group began focusing on supporting leading firms, cooperatives, and family farms. In 2004, local officials decided to offer 242 USD subsidies to farmers who rebuilt more than $10 \mathrm{mu}$ of dry land and 1,208 USD subsidies to farmers who rebuilt more than $50 \mathrm{mu}$ of gentle slope. The reason for this was that the local government wanted to encourage cooperatives and family farms to enter the industry and enhance the degree of clustering and industrialization. To promote agricultural industrialization, the local government also started to facilitate the expansion of an organizational model referred to as 'firm + cooperative + farmers.' This broadly used model involves an agribusiness firm, either processing firm or distribution firm, contracting with smallholders through a farmer cooperative (Guo and Jolly, 2008). The agribusiness firm and tea farmers become shareholders of the cooperative with capital and land-use rights or labor, respectively. In this model, the firm can provide farmers with high-quality inputs, safe production training, standardized production, and a safety management system via the cooperative, and gains stable productions meeting certain quality standards. Both firms and tea farmers benefit from the reduction of transaction costs and risks and improvements in terms of efficiency.

To integrate the resources of enterprises, the county government confirmed 'Kaihua Longding' as a public brand and organized 12 major firms to establish an association in 1997. The association was in charge of instituting rules and administration of the industry to reduce the negative influence of different standards and brands. Concerning standards, the association published the provincial local standards of 'Kaihua Longding' in 1998. Since then, apart from the standards governing the production, processing, and sale, the association added some elements to areas such as quality standards, a supervision and evaluation system, product packaging, and image positioning. Regarding the public brand, the association stipulated that anyone who wanted to use the public brand must get a license from the association in advance. After 2000, the association revised its rules and adopted anti-counterfeiting signs and codes to strictly regulate the use of packaging permits to resolve the quality crisis caused by fake commodities. In 2010, with the increase of 
firms and brands, the association began to implement the 'double trademark' strategy, whereby firms were allowed to use a public trademark and their trademark simultaneously.

Nowadays, the tea cluster mainly adopts the model of 'leading firm + cooperative + farmers' and operates based on market mechanism; industrial organizations coordinate the production of participants in the cluster and improve specialization by reducing information asymmetry and formulating unified standards; and the government mainly provides public services like supervision and guidance for individuals to overcome the market failures within the industrial cluster.

\subsection{Building tea markets}

With the rapid increase in market share, traditional markets were so limited that the local government decided to build a professional tea market in Kaihua County as soon as the association was established. In the early stage of development of the industry, farmers mainly sold tea in the villages. Several scattered, relatively closed traditional markets formed spontaneously in the local area, which led to information asymmetry. Farmers were unable to adjust tea varieties and scale in a timely fashion according to market demand. Moreover, decentralized markets were not conducive to the unification of quality and regional brands. Farmers could only obtain limited income by selling low-quality products or fresh leaves.

In 1998, the county government earmarked 0.2 ha of land to build the professional tea market, which contained more than 200 shops, more than 600 booths, and other facilities, such as industrial and commercial bureau, telecommunications, banks, hotels, and restaurants. Initially, the local government also provided preferential policies relating to fees and taxes to attract farmers and traders to make deals in the professional tea market. According to local government statistics, $95 \%$ of the famous tea was sold in the market in the spring of 1998, and traders purchased 1000-1,500 kilograms of tea per day in the first year after the market opened (Wang, 1999). Moreover, the local government also built some trading districts in the surrounding towns for farmers who were far away from the county. Farmers started to bargain with traders and collect market information from traders from all over China, who were attracted by the professional tea market. On the other hand, according to information from the market, farmers became aware of their disadvantages and spontaneously upgraded skills.

The second phase of development started after the professional tea market in Kaihua County became one of the most important markets in East China in 2001. In 2004, the county government invested 9.06 million USD to build the famous tea market. The total construction area covered 51,000 square meters and included 200 shops, a marketplace for tea sales, and 18 cold storage units with 60 tons of total storage capacity (Editorial Committee of Local Chronicles of Kaihua County, 2010). The market turned out to be a big success. It is a comprehensive distribution center that covers sales, acquisition, storage, packaging, trade negotiations, and other functions. According to the author's survey conducted in 2015, the volume of the tea trade grew constantly until 2010. From 2008 to 2010, the annual volume of tea trading reached 4,500 tons, accounting for $76 \%$ of the total volume in those years. In 2014, 367 merchants were dealing in tea, and traded approximately 4,181.2 tons of tea worth 112.79 million USD, accounting for $71 \%$ of the total volume in Kaihua County.

Professional markets, as public goods built by the local government, became an essential part of the tea cluster. The establishment of tea markets contributes to solving the knowledge gap and reducing the monopoly powers of outside traders. Producers who used to be weak bargainers can sell products and receive information directly through members of the association, which makes it possible to capture more profit along this supply chain. Figure 4 illustrates the current market structure of the tea supply chain and organizations of the tea cluster in Kaihua. Relative to Figure 3, the supply chain and organizations changed completely. 


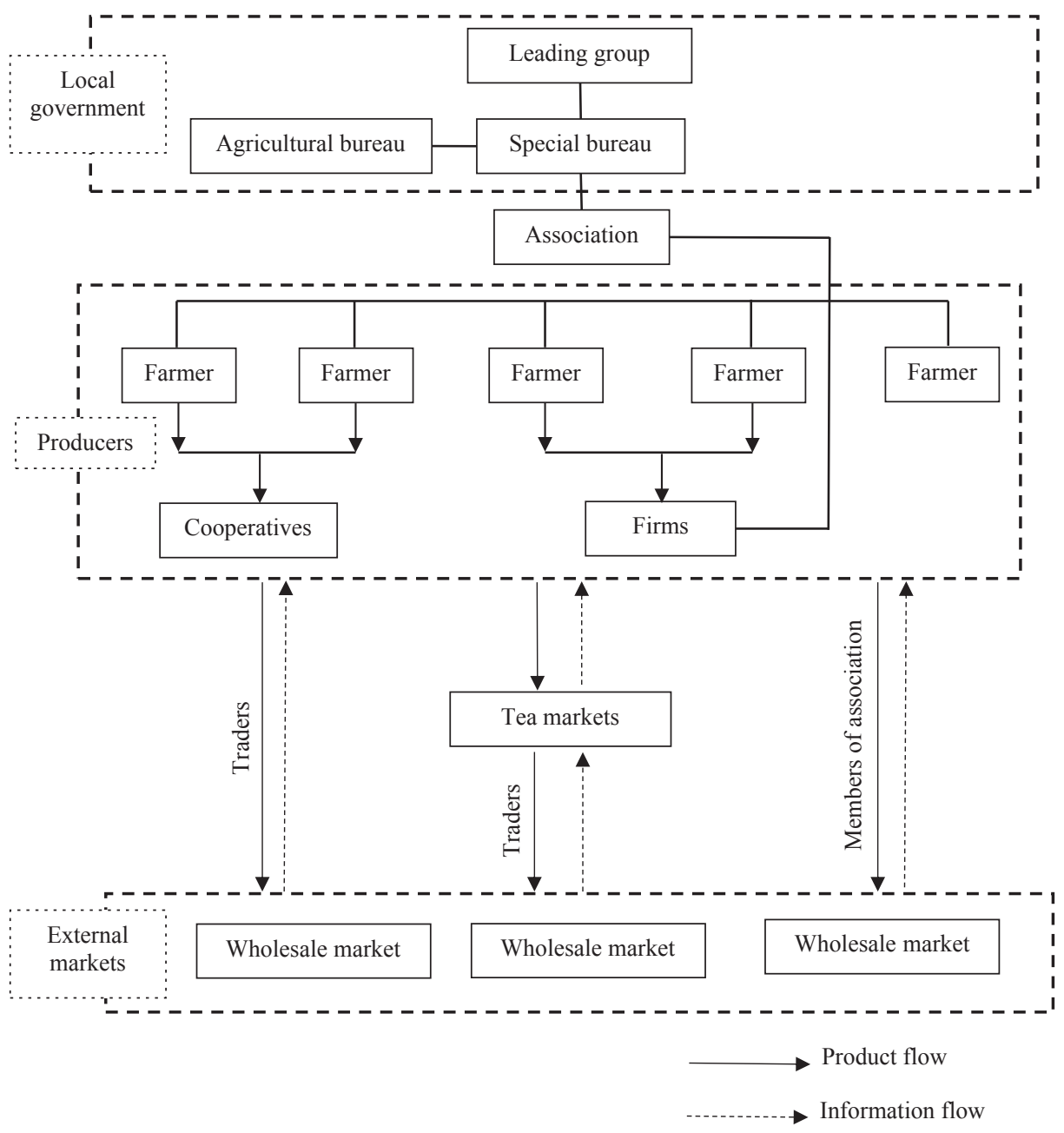

Figure 4. Market structure of the tea supply chain and organizations in 2014.

\subsection{Promoting and managing the brand}

In the early 1990s, most of the tea from Kaihua was sold as a bulk product at a low price. With the success of some famous tea, like West Lake Longjing, the county government started to realize the importance of the regional brand, which no private firm could provide. The regional public brand, 'Kaihua Longding,' came into being with the establishment of the association in 1998.

To develop the public brand, the local government implemented a series of policies to increase the influence of 'Kaihua Longding.' First, the local government subsidized farmers and firms to support their attendance at various expositions. Meanwhile, the local government invested more than 360,000 USD annually to hold activities, such as the 'Kaihua Longding tea party,' which created platforms to popularize 'Kaihua Longding' in major cities such as Beijing and Shanghai. The county government also organized many large-scale events that combined product promotion with travel and culture to enhance the influence of the brand.

Second, the county government was good at using the media to expand the range of influence. In 1998, a local official personally contacted the media and acquired opportunities to advertise on CCTV, German radio, and television. With the development of new media, the local government tried to promote tea products in various ways. For example, in 2009, the county government helped to create a film named 'Long Ding' and celebrated the traditional festivals of 'Kaihua Longding' on the Internet. 
The public brand, Kaihua Longding, is trusted and favored by consumers because of its high quality and visibility. Figure 5 shows that brand value increased in recent years, and the ranking rose from $24^{\text {th }}$ to $21^{\text {st }}$ among all the tea brands.

Even though the regional public brand, which is a quasi-public good, creates positive externalities, it raises some problems like free ride problems, prisoner's dilemma, and the lemons market. A public good has two key characteristics: it is non-excludable and non-rivalrous (Samuelson, 1954). Firms with permission are free to use the public brand when selling products. However, the risk may appear if some low-quality users, even firms outside the cluster, make use of the public brand without any additional cost. In response, the local government became an active participant in dialogs with cluster participants and designed some industrial policies to raise barriers to entry and cost of misuse, thus protecting the regional public brand.

\subsection{Comparison with Qujiang District}

This study examines Qujiang District, which is close to Kaihua geographically, as a comparison. Qujiang District, formerly Quxian County, is located in Quzhou and was one of the main tea-producing areas in western Zhejiang. It is close to Kaihua, and the natural conditions of these two counties are quite similar. However, the tea industry in Qujiang District developed slowly due to the lack of timely formulation of industrial policies by the local government.

The tea industry in Qianjiang District began in the 1960s and peaked in the 1980s. In 1974, the Ministry of Agriculture listed Qujiang as one of the 100 counties that were able to produce more than 2,500 tons of green tea. Tea became the way for farmers, especially for those who lived in the mountainous areas, to obtain income. The production area for tea reached 3,467 ha, with 960 tons of tea in Qujiang, and the tax revenue of tea accounted for more than $10 \%$ of the district's fiscal revenue in 1988. However, the efficiency of tea production declined because most of the tea farmers adopted local varieties that aged rapidly. The proportion of clonal cultivars was low in the early stage of the industry, and it was only $8.9 \%$ in 2004 . As for the industrial organization, there was a large-scale collective tea farm in Qujiang during the period of the collective economy. However, after implementation of the household contract system, the tea farm was divided and averaged out between households, and more than $80 \%$ of the tea gardens were managed in a dispersed way by small households. Gradually, farmers turned away from the tea industry because the income from tea made up a lower proportion of their total income. In the 1990s, the area and output of tea gardens declined and bottomed out. Most farmers began to replant economically profitable trees, such as chestnut and fruit trees, in place of tea.

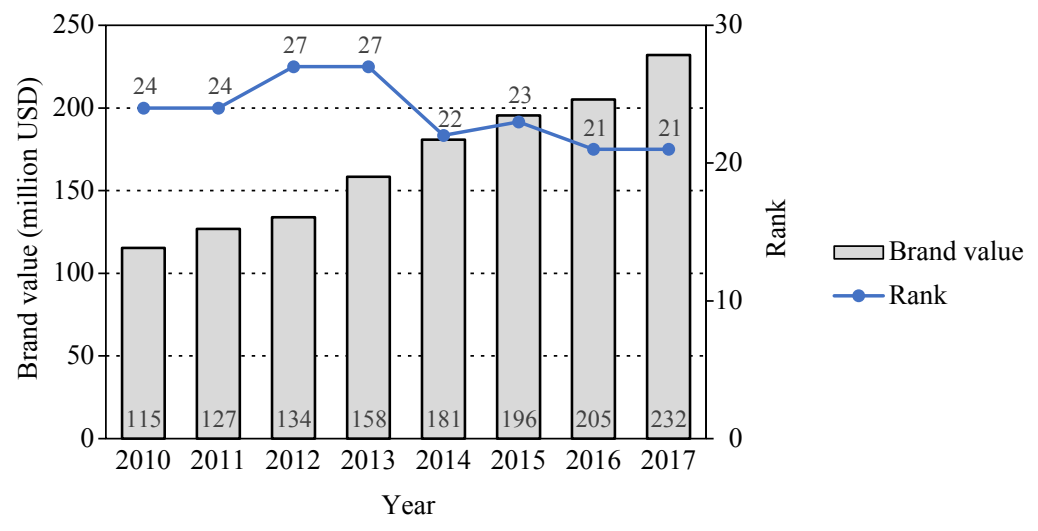

Figure 5. Brand value and rank of 'Kaihua Longding' (2010-2016) (Hu et al., 2016). Brand value is based on the price level in 2004. 
Since 2002, the local government designed industrial policies for tea and subsidized the promotion of improved varieties. In 2005, tea cooperatives were established to train farmers, improve the technical level of local tea farming, and increase farmers' income. The output increased by 750 kilograms, from 465 kilograms per ha, and the average price rose by approximately $20 \%$ per kilogram as farmers began growing organic tea. There were more tea gardens in Qujiang than before as farmers returned to the tea industry. In 2010, there were 2,233 ha of tea gardens, 570 ha of which were used for growing clonal variety tea, accounting for $25.5 \%$ of the total tea garden area in Qianjiang. In 2013, the proportion of clonal varieties planted exceeded $65 \%$ in some tea gardens, but the overall proportion was only $30 \%$, which was less than half of that in Kaihua. There were 26 large-scale households that managed tea gardens with more than 3.3 ha (313 ha in total), and the area of large-scale tea gardens accounted for $17.3 \%$ of the total area in Qujiang.

The tea industry in Qianjiang still faced some problems, such as brand building, when Qianjiang began to engage in the new market environment. In the development of the industry in Kaihua, the local government established the regional brand 'Kaihua Longding,' with positive externalities through policies, and it formulated policies such as quality supervision and promotion of the brand. However, there are many individual brands other than the regional brand in Qujiang. Moreover, the local government did not implement specific policies relating to regional brand building, and the tea companies in Qujiang could not integrate and compete in the market like their competitors in Kaihua. These independent brands have a certain reputation in the local market, but they are not well known in the external market. Some tea products were sold with individual brands or regional brands from other counties by small households. In 2013, tea products from Qujiang in the local market were affected by competitors, such as 'Kaihua Longding' from other counties, with sales accounting for only $37 \%$ of total sales in the local market. And the price was at rock bottom: as shown in Figure 6, the average tea price in Qianjiang is much lower than is that in Kaihua due to quality and brand influence, although it increased in recent years.

\section{Discussion}

\subsection{Discussion of the research questions}

This study explores the local industrial policies and their role in developing agricultural clusters by taking the tea cluster in Kaihua as an example. Policymaking is a complex process influenced by natural and socio-economic conditions such as external market and industrial dynamics (Ju et al., 2015; Lin, 2019). This suggests that the path of industrial development in different counties is diverse because each region has its comparative advantages (Zhang and $\mathrm{Hu}, 2014$ ). Keeping this in mind, this study reported on local industrial policy and the development of agricultural clusters by demonstrating the industrial policies that the local

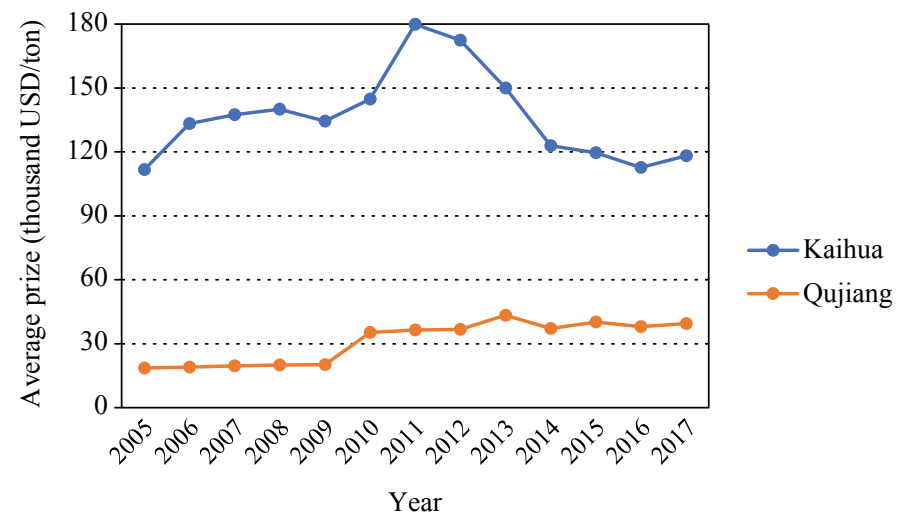

Figure 6. Tea price in Kaihua County and Qujiang District (2005-2017) (Quzhou Bureau of Statistics, 2018). 
government designed to support the growth and evolution of agricultural clusters in the Chinese context. Specifically, this study discusses how local governments formulate effective industrial policies at different stages of the cluster in Kaihua to lower the barriers to entry of new farmers and support the development of the tea cluster, which is conducive to increasing farmers' income. The use of industrial policies as instruments to solve market failure to upgrade clusters is also discussed.

At the outset of the research, this study raises two questions. From the Kaihua tea cluster case, the answers can be concluded as follows:

\section{- What industrial policies were designed during the development of the agricultural industrial cluster in China?}

This case study reveals that industrial policies are important in the development of industrial clusters. The government can adopt industrial policies to turn the industries of an economy's comparative advantages into the economy's competitive advantages in domestic and international markets (Lin, 2019). Nature endows Kaihua County with advantageous conditions to develop the tea industry. However, it used to be undeveloped, and most tea farmers lacked their capital and abilities for R\&D and management. Combined with the fact that there were few industrial organizations, farmers captured a little profit along the supply chain from producers to consumers due to weak bargaining power. Given the endowment structure and external market, the Kaihua government designed and implemented a series of industrial policies to address these issues.

First, in the early stage, the local government helps farmers overcome production bottlenecks. Risk-averse farmers are unwilling and unable to be the first mover to use improved varieties and machines. The local government provides industrial policies and financial support to encourage farmers to cultivate new varieties and purchase professional machines, which promote the diversification and standardization of products.

Second, the local government established industrial organizations when a quality crisis emerged after the period of industrial expansion. Governmental agencies integrate stakeholders, including farmers and firms, and set up an association of industry in the first place. Then, the association institutes rules and administration of the industry to improve specialization based on market mechanisms, and the local government mainly provides public service to private producers and industrial organizations.

Third, the local government provides infrastructures such as markets. Small farmers cannot afford to build a professional market, which is essential in the flow of products and information. It requires the local government to build markets that contribute to improving the supply chain and solving the knowledge gap.

Fourth, the local government promotes and manages the public brand as another public good at the stage of brand innovation. Promoting public brands has strong positive externalities, such as enhancing the visibility and credibility of products, which help to expand market share. To better manage the public brand, the local government should design industrial policies to raise barriers to entry and cost of misuse and thus protect the regional public brand.

As discussed, these industrial policies lead to the expansion and upgrading of local tea clusters and sustainable benefits for farmers in Kaihua. Contrastingly, the tea industry in Qianjiang District, where initial conditions are quite similar to Kaihua, stagnated because of the lack of timely policies. The results of this case suggest that designing policies based on the requirements of industrial clusters is more effective. 


\section{- What can be considered an effective industrial policy?}

Despite the pivotal role of government intervention in industrial development and economic growth as shown in some studies (Cimoli et al., 2009), Rodrick (2009) argues that how to design industrial policy effectively is more important by pointing out 'industrial policy: don't ask why ask how.' It seems that designing effective industry policies is more realistic.

First, effective industrial policies should be designed based on market and comparative advantages. The economic structures of counties in different stages of development are qualitatively different, and thus may entail different principles for economic operation. The local government should provide functional industrial policies according to market demand instead of the intervening market through selective industrial policies, which may lead to inefficiencies in the development of industrial clusters.

Second, the purpose of effective industrial policies is to overcome the market failures encountered in the evolution of clusters. Industrial and regional characteristics exist in the dynamic evolution of local clusters, which will affect the development of industrial clusters. It is significant for industrial clusters to maintain competitiveness whether the local government can provide appropriate public goods. An improvement in hard infrastructure, such as improved varieties and markets, and soft infrastructures, such as industrial organizations and public brands, is used to reduce the cost of transactions inside the cluster and promote the development of industrial clusters.

Third, the design of effective industrial policies is also a dynamic process. It is difficult for the central government to design a national strategy that is applied to all locations at any given time. In comparison, local governments have better access to information about the binding constraints faced by firms and, therefore, are in a better position to come up with practical solutions. Moreover, the local government can decide when to continue implementing or altering industrial policies more quickly based on the dynamic market and the development of industrial clusters.

\subsection{Theoretical and policy contributions}

The findings of this study make theoretical contributions to policymaking in the development of clusters. This study also shows that it is possible for the local government with comparative advantages to achieve sustained development of agriculture based on effective industrial policies.

First, the findings in this study support the viewpoints proposed by Lin (2016) and Wang (2017) that both efficient markets and facilitating states play important roles in industry development. Some studies argue that there are few successful cases of industrial policies due to ignorance of governments (Zhang, 2016). However, the case of Kaihua confirms that an effective initial policy is not the same as a perfect plan ahead, but that the local government is willing and able to provide corresponding public goods and services when specific challenges occur at different stages of industrial development.

Second, this study fills the gaps in the literature on local industrial policies and agricultural clusters. Because of the difference in natural conditions across regions, it is difficult for a central government to design a unified national agricultural development strategy that applies to all locations (Zhang and $\mathrm{Hu}, 2014$ ). The case of Kaihua demonstrates that the local government is more sensitive to the specific needs of the participants in the cluster and designs local industrial policies to promote regional development. The case study also relates to agricultural development in undeveloped regions. The debate on industrial policies focused mainly on specific policies for non-farm sectors such as the vehicle and electronic industry (Lin, 2016; Zhang, 2016), whereas developing agriculture is the key to increasing the poor's income and against poverty in developing countries. The tea cluster explicates what industrial policies the local government designed to promote agricultural clusters when market failures occur in the context of a developing country. It further illustrates what can be considered an effective industrial policy in an agricultural context. 
Third, the findings highlight the importance of effective industrial policies for fostering agricultural clusters in a poor county like Kaihua, and also provide theoretical support and methodological guidance for the future development of agricultural clusters in relatively undeveloped regions with comparative advantages, such as the counties in Midwest China and those beyond China.

Fourth, this study also provides an example of developing countries for application. The most crucial point is that local governments have an essential role in assembling information about comparative advantages and domestic constraints. Compared with the central government, local governments can identify gaps and weaknesses in industrial policies more quickly and promote the development of industries and continuous economic growth through the design and implementation of corresponding industrial policies.

\section{Conclusions}

In conclusion, this study describes the effects of local industrial policies on the development of local industries based on the case of tea clusters. Due to different factors, 'picking winners' may not be suitable in most cases while the government needs to provide services, such as hard and soft infrastructure and other public goods to support industrial clusters based on market discipline. As industrial development is a continuous process, a cluster will encounter different environmental constraints at different stages. Compared with industrial policies at the local level, the central government tends to implement inclusive policies, such as regional industrial planning and adjustment of interest rates and tax rates, which apply to large regions, at the provincial level and above. However, problems such as information asymmetry and externalities may exist, making it difficult for the central government to formulate an industrial policy that can be applied to all regions. It requires local governments to strengthen their ability to remain sensitive to information about participants and potential market failure in clusters to produce effective industrial policies depending on the actual situation. The findings of this study make theoretical contributions to the literature on effective industrial policies and make policy contributions to local governments in undeveloped regions for policymaking in the development of agricultural clusters.

There are some limitations to this study. First, the tea cluster in China is only based on one county; the single case study methodology may not represent the risk of misjudgment. Although we use the Qujiang District as a comparison, it is still limited because of the unavailable information. Future studies may thus adopt a multiple-case study to explain why industrial policies succeed or fail and, more importantly, they are universally applicable to other regions with similar conditions. Second, most governments in developing countries may not possess a strong governmental capacity and sensibility like Kaihua. Therefore, case studies in other undeveloped regions need to be put to support the viewpoint in the future. In practice, it may be too demanding for those local governments, which lack necessary incentives and capacities to design effective industrial policies. It requires facilitating states when generalizing the case of the tea cluster in Kaihua.

\section{Acknowledgements}

Funding supports from the Natural Science Foundation of China (71873121 and 72003170 ), Ministry of Education of China (15JJD790033) and Soft Science Research Project of Zhejiang (2020C35047) are gratefully acknowledged.

The authors want to thank Mr. Jianqiang Lian who provided support in the survey.

\section{References}

Aghion, P. 2014. Commentary: the case for industrial policy. In: J. Stiglitz and B. Greenwald (eds.) Creating a learning society. Columbia University Press, New York, USA.

Aghion, P., J. Cai., M. Dewatripont., L. Du., A. Harrison and P. Legros. 2015. Industrial policy and competition. American Economic Journal: Macroeconomics 7(4): 1-32. https://doi.org/10.1257/mac.20120103 
Altenburg, T and W. Lütkenhorst. 2015. Industrial policy in developing countries: failing markets, weak states. Edward Elgar Publishing Limited, Cheltenham, UK.

Baldwin, R.E. 1969. The case against infant industry tariff protection. Journal of Political Economy 77(3): 295-305. https://doi.org/10.1086/259517

Bruhn, M., D. Karlan and A. Schoar. 2010. What capital is missing in developing countries? American Economic Review 100(2): 629-633. https://doi.org/10.1257/aer.100.2.629

Chang, H. 2003. Kicking away the ladder: development strategy in historical perspective. Anthem, London, UK.

Chang, H. 2006. The East Asian development experience: the miracle, the crisis and the future. Zed Books, London, UK.

Chen, X., T. Zhang and F. Jia. 2020. Industry convergence as a strategy for achieving sustainable development of agricultural complex: the case of Sandun-Lanli in China. Business Strategy and the Environment 29: 2679-2694. https://doi.org/10.1002/bse.2529

Cheng, X. and G. Yu. 2009. Kaihua Longding was reelected as the top ten teas in Zhejiang Province. Zhejiang Forestry 7: 29. (in Chinese)

Chinese Tea Brand Value Assessment Research Group. 2017. Evaluation report on regional public brand value of tea in China (2010-2017). China Tea. (in Chinese)

Cimoli, M., G. Dosi and J. Stiglitz. 2009. Industrial policy and development: the political economy of capabilities accumulation. Oxford University Press, New York, NY, USA.

Committee on Literature and History of CPPCC of Kaihua. 1999. Cultural and historical materials in Kaihua County, $6^{\text {th }}$ series. Kaihua Longding. (in Chinese)

Editorial Committee of Forestry Chronicles of Kaihua County. 2011. Forestry annals of Kaihua: 1986-2010. China Local Records Publishing, Beijing, China. (in Chinese)

Editorial Committee of Local Chronicles of Kaihua County. 2010. County annals of Kaihua: 1986-2005. China Local Records Publishing, Beijing, China. (in Chinese)

Editorial Committee of Local Chronicles of Kaihua County. 2015. Kaihua yearbook (2008-2013). China Local Records Press, Beijing, China. (in Chinese)

Evans, P.B. 1995. Embedded autonomy: states and industrial transformation. Princeton University Press, Princeton, NJ, USA.

Evenett, S. 2003. Study on issues related to a possible multilateral framework on competition policy. World Trade Organization, Geneva, Switzerland.

Galli, F., F. Venturi, F. Bartolini, O. Gava, A. Zinnai, S. Chiara, G. Andrich and G. Brunori. 2017. Shaping food systems towards improved nutrition: a case study on Tuscan Bread Protected Designation of Origin. International Food and Agribusiness Management Review 20(4): 533-552. https://doi. org/10.22434/IFAMR2015.0174

Greenwald, B. and J. Stiglitz. 2013. Industrial policies, the creation of a learning society, and economic development. In: J. Stiglitz and J.Y. Lin (eds.) The industrial policy revolution: the role of government beyond ideology. Palgrave Macmillan, New York, NY, USA.

Guo, H. and R. Jolly. 2008. Contractual arrangements and enforcement in transition agriculture: theory and evidence from China. Food Policy 33: 570-575. https://doi.org/10.1016/j.foodpol.2008.04.003

Hatta, T. 2017. Competition policy vs. industrial policy as a growth strategy. China Economic Journal 10(2): 162-174. https://doi.org/10.1080/17538963.2017.1321216

Hausmann, R. and D. Rodrik. 2003. Economic development as self-discovery. Journal of Development Economics 72(2): 603-633. https://doi.org/10.1016/S0304-3878(03)00124-X

Hu, P. and D. Zheng. 2015. Farmers make money depend on Kaihua Longding. Available at: http://khnews. zjol.com.cn/khnews/system/2015/05/07/019309127.shtml. (in Chinese)

Hu, X., C. Wei and Q. Zhang. 2016. Evaluation report on regional public brand value of tea in China, 2016. China Tea 5: 4-11. (in Chinese)

Huang, J. 2018. What is a good industrial policy? In: J.Y. Lin, J. Zhang, Y. Wang and Z. Kou (eds.) Industrial policy: summary, reflection and prospect. Peking University Press, Beijing, China, pp. 51-57. (in Chinese) 
Itoh, M., K. Kiyono., M. Okuno and K. Suzumura. 1991. Economic analysis of industrial policy. Academic Press, New York, NY, USA.

Jia, F., R. Gao., R. Lamming and R. Wilding. 2016. Adaptation of supply management towards a hybrid culture: the case of a Japanese automaker. Supply Chain Management 21(1): 45-62. https://doi. org/10.1108/SCM-01-2015-0009

Johnson, C. 1982. MITI and the Japanese miracle: the growth of industrial policy: 1925-1975. Stanford University Press, Redwood City, CA, USA.

Ju, Y. 1998. The competition of famous tea in large market. In: Committee on Literature and History of CPPCC of Kaihua (eds.) Cultural and historical materials in Kaihua County, $6^{\text {th }}$ series. Kaihua Longding, China.

Ju, J., J.Y. Lin and Y. Wang. 2015. Endowment structures, industrial dynamics, and economic growth. Journal of Monetary Economics 76: 244-263. https://doi.org/10.1016/j.jmoneco.2015.09.006

Kaihua Government. 2018. Statistical bulletin of national economy and social development in Kaihua County 2005-2018. Kaihua Government. Available at: http://www.kaihua.gov.cn/col/col1388994/ index.html (in Chinese).

Kang, D. 2002. Crony capitalism: corruption and development in South Korea and the Philippines. Cambridge University Press, Cambridge, UK.

Krueger, A. 1974. The political economy of rent-seeking society. American Economics Review 64(3): 291303. https://doi.org/10.1007/978-3-540-79247-5_8

Krugman, P. 1993. Protection in developing countries. In: R. Dornbusch (eds.) Policymaking in the open economy: concepts and case studies in economics performance. Oxford University Press, New York, NY, USA, pp. 127-148.

Krugman, P. and M. Obstfeld. 2009. International economics: theory and policy, $7^{\text {th }}$ edition. Pearson-Addison, New York, NY, USA.

Lall, S. 2001. Comparing national competitive performance: an economic analysis of world economic forum's competitiveness index. Queen Elizabeth House Working Paper No. 61. University of Oxford, Oxford, UK.

Lee, J., I. Clacher and K. Keasey. 2012. Industrial policy as an engine of economic growth: a framework of analysis and evidence from South Korea (1960-96). Business History 54(5): 713-740. https://doi.org $/ 10.1080 / 00076791.2012 .683420$

Lin, J., C. Monga, D.W. Te Velde, S.D. Tendulkar, A. Amsden, K.Y. Amoako, H. Pack and W. Lim. 2011. DPR debate growth identification and facilitation: the role of the state in the dynamics of structural change. Development Policy Review 29(3): 298-301. https://doi.org/10.1111/j.1467-7679.2011.00534.x

Lin, J.Y. 2009. Economics development and transition: thought, strategy, and viability. Cambridge University Press, Cambridge, UK.

Lin, J.Y. 2010. Six steps for strategic government intervention. Global Policy 1(3): 330-331. https://doi. org/10.1111/j.1758-5899.2010.00036.x

Lin, J.Y. 2016. Industrial policy and economic development: perspective from new structural economics. Comparative Studies 6. (in Chinese)

Lin, J.Y. 2019. New structural economics: the third generation of development economics. Asian Education and Development Studies 9(3): 279-286. https://doi.org/10.1108/AEDS-02-2019-0039

Lin, J.Y. and H. Chang. 2009. Should industrial policy in developing countries conform to comparative advantage or defy it? A debate between Justin Lin and Ha-Joon Chang. Development Policy Review 27(5): 483-502. https://doi.org/10.1111/j.1467-7679.2009.00456.x

Long, C. and X. Zhang. 2012. Patterns of China's industrialization: concentration, specialization, and clustering. China Economic Review 23(3): 593-612. https://doi.org/10.1016/j.chieco.2011.09.002

Luo, B., K. Li., J. Wang and Z. Wu. 2002. Agricultural industrial organization: evolution, comparison and innovation: research on institutional economics based on the division of labor. Economic Press China, Beijing, China. (in Chinese)

Olson, M. 2000. Power and prosperity: outgrowing communist and capitalist dictatorships. Basic Books, New York, NY, USA. 
Organisation for Economic Cooperation and Development (OECD). 2013. Perspectives on global development 2013: industrial policies in a changing world. OECD Development Centre, Paris, France.

Otsuak, K. 2017. Role of local institutions in the development of industrial clusters. In: N. Cooray and S. Abeyratne (eds.) Decentralization and development of Sri Lanka within a unitary state. Springer, Singapore, pp. 245-265.

Pack, H. and K. Saagi. 2006. Is there a case for industrial policy? a critical survey. World Bank Research Observer 21(2): 267-297. https://doi.org/10.1093/wbro/lk1001

Quzhou Bureau of Statistics. 2018. Quzhou statistical yearbook (2004-2017). China Statistics Press, Beijing, China. (in Chinese)

Rodrik, D. 1996. Coordination failures and government policy: a model with applications to East Asia and Eastern Europe. Journal of International Economics 40: 1-22. https://doi.org/10.1016/00221996(95)01386-5

Rodrik, D. 2008. Normalizing industrial policy. Commission on Growth Working Paper No. 3. World Bank, Washington, DC, USA.

Rodrik, D. 2009. Industrial policy: don't ask why, ask how. Middle East Development Journal 1(1): 1-29. https://doi.org/10.1142/S1793812009000024

Ruan, J., Q. Shi and X. Zhang. 2014. Dynamic evolution law of industrial clusters and local governmental policies. Management World 12: 79-91. https://doi.org/10.19744/j.cnki.11-1235/f.2014.12.008 (in Chinese)

Rui, Z. 1999. Cultivation of improved varieties and construction of bases. In: Committee on Literature and History of CPPCC of Kaihua (eds.) Cultural and historical materials in Kaihua County, $6^{\text {th }}$ series. Kaihua Longding, China.

Samuelson, P. 1954. The pure theory of public expenditure. The Review of Economics and Statistics 36(4): 387-389. https://doi.org/10.2307/1925895

Smith, A. 2011. An inquiry into the nature and causes of the wealth of nations. The Commercial Press, Beijing, China. (in Chinese)

Sonobe, T. and K. Otsuka. 2006. Cluster-based industrial development: an East Asia model. Palgrave Macmillan, New York, NY, USA.

Stiglitz, J. 2015. Industrial policy, learning, and development. WIDER working paper (wp-2015-149). World Institute for Development Economic Research, Helsinki, Finland.

Stiglitz, J. and B. Greenwald. 2014. Creating a learning society: a new approach to growth, development, and social progress. Columbia University Press, New York, NY, USA.

Stiglitz, J. and S. Yusuf. 2001. Rethinking the East Asian miracle. World Bank Publications, Washington, DC, USA.

Su, D. 2010. Industry economics. Higher Education Press, Beijing, China. (in Chinese)

Tassinari, M., E. Barbieri., G. Morleo and M. Tommaso. in press. Targeted industrial policy and government failures: insights from the South Korean experience. International Journal of Emerging Markets. https://doi.org/10.1108/IJOEM-02-2018-0110

Voss, C., N. Tsikriktsis and M. Frohlich. 2002. Case research in operations management. International Journal of Operations \& Production Management 22(2): 195-219. https://doi.org/10.1108/01443570210414329

Wang, Q. 1999. Professional tea market of Kaihua Longding. In: Committee on Literature and History of CPPCC of Kaihua (eds.) Cultural and historical materials in Kaihua County, $6^{\text {th }}$ series. Kaihua Longding, China.

Wang, H. and J. Huang. 2016. Farmers' risk and pooling risk preferences. Issues in Agricultural Economy 11: 86-94, 112. https://doi.org/10.13246/j.cnki.iae.2016.11.010 (in Chinese)

Wang, X. 2017. The effects of mechanization on growing tea. China Agricultural Mechanization Newspaper. June, 2017. (in Chinese).

Wang, Y. 2015. A model of sequential reforms and economic convergence: the case of China. China Economic Review 32: 1-26. https://doi.org/10.1016/j.chieco.2014.10.009

Warwick, K. 2013. Beyond industrial policy: emerging issues and new trends. OECD Science, Technology and Industry Policy Papers No. 2. OECD Publishing, Paris, France. 
Williams, S. 1993. Japenese industrial policy: what is it, and has it worked? Canada-United Law Journal 19: 79-92.

Yang, G. and J. Cao. 2011. High quality makes tea industry become the main way for farmers to increase income in Kaihua County. China Quality Daily, July 7, 2011. (in Chinese)

Yin, R. 2009. Case study research: design and methods, $4^{\text {th }}$ edition. Sage, Thousand Oaks, CA, USA.

Yu, X. 2015. Current situation and countermeasure of Kaihua County tea industry. China Tea Processing 1: 63-66. https://doi.org/10.15905/j.cnki.33-1157/ts.2015.01.014 (in Chinese)

Zhang, W. 2016. Why I oppose industrial policy: debate with Justin Yifu Lin. Comparative Studies 6. (in Chinese)

Zhang, X. and D. Hu. 2014. Overcoming successive bottleneck: the evolution of a potato cluster in China. World Development 63: 102-112. https://doi.org/10.1016/j.worlddev.2013.10.003

Zhang, X. and J. Ruan. 2011. The evolution of industrial clusters in China. Zhejiang University Press, Hangzhou, China. (in Chinese)

Zhu, G. 1999. Distribution of tea plantations. In: Committee on Literature and History of CPPCC of Kaihua (eds.) Cultural and historical materials in Kaihua County, $6^{\text {th }}$ series. Kaihua Longding, China. 